\title{
Maternal malnutrition during lactation alters the folliculogenesis and gonadotropins and estrogen isoforms ovarian receptors in the offspring at puberty
}

\author{
Tatiane da Silva Faria, Flávia de Bittencourt Brasil, Francisco J B Sampaio and Cristiane da Fonte Ramos \\ Urogenital Research Unit-UERJ, State University of Rio de Janeiro, Avenue 28 de Setembro, 87, Fundos, FCM, Terreo, 20551-030 Rio de Janeiro, RJ, Brazil \\ (Correspondence should be addressed to C da Fonte Ramos; Email: cristiane@pesquisador.com.br)
}

\begin{abstract}
In this study, we aimed to evaluate whether maternal malnutrition during lactation alters the folliculogenesis and the expression of the gonadotropins and estrogen isoforms ovarian receptors in the offspring at puberty. At parturition, dams were randomly assigned to the following groups: control (C) group, with free access to a standard laboratory diet containing 23\% protein and protein-energy-restricted (PER) group, with free access to an isoenergy and protein-restricted diet containing $8 \%$ protein. After weaning, the female pups had free access to standard laboratory diet. The maternal malnutrition caused a significant increase in the number of preantral $(C=13 \cdot 72 \pm 2 \cdot 87 ; \mathrm{PER}=26 \cdot 36 \pm 3 \cdot 03, P<0 \cdot 01)$ and small antral follicles $(C=9 \cdot 32 \pm 1 \cdot 35$; PER $=17 \cdot 64 \pm$ $2 \cdot 33, P<0 \cdot 01)$ and decrease in the number of primordial $(C=11.72 \pm 1 \cdot 37 ; \mathrm{PER}=3.92 \pm 0 \cdot 60, P<0 \cdot 01)$ and Graafian follicles $(C=1 \cdot 84 \pm 0 \cdot 21 ; \mathrm{PER}=0 \cdot 96 \pm 0 \cdot 11, P<0 \cdot 01)$, and corpus luteum $(C=2 \cdot 00 \pm 0 \cdot 28 ; \operatorname{PER}=0 \cdot 80 \pm 0 \cdot 31$, $P<0 \cdot 01)$. The estradiol serum concentration was significantly higher $(C=67 \cdot 86 \pm 4 \cdot 39 ; \quad \operatorname{PER}=83 \cdot 29 \pm 2 \cdot 68, \quad P<0 \cdot 05)$ while testosterone serum concentration did not show statistical
\end{abstract}

difference $(C=0 \cdot 09 \pm 0 \cdot 02 ; \mathrm{PER}=0 \cdot 11 \pm 0 \cdot 01, P>0 \cdot 05)$ in the PER group. In relation to the receptors expression, maternal malnutrition led to a significant increase in the amount of Fshr $(C=0.89 \pm 0.04 ; \quad$ PER $=1.07 \pm 0.03$, $P<0.05)$ and Lhcqr $(C=0.87 \pm 0 \cdot 15 ;$ PER $=1 \cdot 33 \pm 0.08$, $P<0 \cdot 05)$ transcripts and a significant decrease in the amount of $\operatorname{Ar}(C=0.59 \pm 0 \cdot 006$; PER $=0 \cdot 13 \pm 0 \cdot 080, P<0 \cdot 05), E R \alpha$ (Esr1) $(C=3 \cdot 33 \pm 0 \cdot 71 ; \mathrm{PER}=0 \cdot 74 \pm 0 \cdot 50, P<0 \cdot 05), E R \beta 1$ (Esr2) $(C=1.33 \pm 0.06 ; \mathrm{PER}=0.49 \pm 0 \cdot 36, P<0 \cdot 05)$, and $E R \beta 2(E s r 2)(C=3 \cdot 28 \pm 0 \cdot 60 ; \mathrm{PER}=0 \cdot 62 \pm 0 \cdot 34, P<0 \cdot 05)$ transcripts. In conclusion, perinatal maternal malnutrition can directly affect folliculogenesis at puberty probably as a consequence of changes in the ovarian expression of gonadotropins, androgen and estrogens isoforms receptors. Long-term sexual alterations could be expected in this experimental model, since a reduction in the primordial follicle number is observed, which can result in a decrease in the reproductive lifetime and an earlier termination of breeding capacity.

Journal of Endocrinology (2008) 198, 625-634

\section{Introduction}

In mammals, the ability of the ovary to produce dominant follicles that ovulate their oocytes at mid-cycle is the basis of female fertility. In the adult ovary, folliculogenesis starts when follicles leave the pool of resting follicles to enter the growth phase. Thereafter, the early growing follicle undergoes a developmental process including a dramatic course of cellular proliferation and differentiation through primordial, primary, and secondary stages before acquiring an antral cavity. Most follicles fail to reach the preovulatory stage every cycle, dying in the process termed atresia (Gougeon 1996).

The gonadotropins, luteinizing hormone ( $\mathrm{LH}$ ) and folliclestimulating hormone (FSH), act by binding to and activating their specific receptors, LH receptor (LHR) and FSH receptor (FSHR; McFarland et al. 1989, Sprengel et al. 1990, Richards 1994). LHR is mainly expressed in ovarian theca cells, but it is also present in granulosa cells of preovulatory follicles and corpora lutea, whereas FSHR is expressed exclusively in granulosa cells (Themmen \& Huhtaniemi 2000).

Fully differentiated preovulatory follicles are responsive to FSH and characterized by an increased capacity to synthesize large amounts of estradiol via aromatization of thecal-derived androgens, formation of a large fluid-filled antrum, and the acquisition of LHR (Richards et al. 2002, Couse et al. 2005). The LH surge promotes major changes in ovarian preovulatory follicles, including terminal differentiation of follicular cells and oocyte maturation. These events are required for the ovulation of a fertilizable egg (Hizaki et al. 1999), but it is clear that many other signaling events are critical for the final follicle growth and eventual ovulation. These include specific nuclear hormone receptors as progesterone receptors (Lydon et al. 1995, Robker et al. 
2000, Conneely et al. 2001), leptin (Ryan et al. 2003, Ricci et al. 2006), several local growth factors (Vitt et al. 2000, Shimada et al. 2006), prostaglandins (Wong \& Richards 1991, Sirois et al. 1992, Davis et al. 1999, Joyce et al. 2001), insulin (Tamura et al. 2007), and others.

Besides gonadotropins, sex steroids play important roles in the growth and differentiation of reproductive tissues and in the maintenance of fertility. The biological actions of estrogens are mediated by binding to one of the two specific estrogen receptors (ERs), ER $\alpha$ or ER $\beta$, which belong to the nuclear receptor superfamily (Clark et al. 1992, Korach et al. 1995).

$\mathrm{ER} \alpha$ and $\mathrm{ER} \beta$ are products of distinct genes on different chromosomes (Chu \& Fuller 1997, Chun et al. 1998). Several ER $\alpha$ and $\operatorname{ER} \beta$ splicing variants have been described. Unlike $E R \alpha$, several splice variants of $E R \beta$ are expressed in tissues and the isoforms $E R \beta 1$ and $E R \beta 2 \mathrm{mRNAs}$ coexist in most rat organs including the ovary and uterus (Petersen et al. 1998, Price \& Handa 2000). The ER $\beta 1$ mRNA sequence represents all eight exons identified so far in the $E R \beta$ gene. $E R \beta 2$ contains an additional 54 nt between exons 5 and 6 . Thus, this transcript encodes a protein with 18 additional amino acids in the ligand-binding domain (Maruyama et al. 1998, Petersen et al. 1998). ER $\beta 2$ has a lower ligand-binding affinity when compared with ER $\beta 1$ (Petersen et al. 1998). ER $\beta 2$ acts as a homodimer and it does not have the ability to induce transcription and even inhibits transcriptional activity of $E R \alpha$ and $E R \beta 1$ (Maruyama et al. 1998).

Although ER $\alpha$ and ER $\beta$ share similar mechanisms of action, several differences in the transcriptional abilities of each receptor as well as distinct phenotypes between genenull animals have been identified, suggesting that these receptors may regulate distinct cellular pathways. When ERs are coexpressed, ER $\beta$ exhibits an inhibitory action on ER $\alpha$ mediated gene expression (Paech et al. 1997, Liu et al. 2002, Lindberg et al. 2003).

Estrogens acting via its receptors have direct proliferative and differentiative influences on follicle development, depending on the stage of folliculogenesis (Drummond \& Findlay 1999). The ovary contains both ER subtypes, with a predominance of ER $\beta$ over ER $\alpha$ in granulosa cells (Byers et al. 1997, Drummond et al. 1999).

The follicular production of estrogen is dependent on the production of testosterone in theca cells and aromatase activity in the granulosa cells of the ovary in response to LH. The presence of androgen receptors (AR) suggests that this hormone can have specific actions in the ovary (Kimura et al. 2007). Besides serving as estrogen precursors, in rats, androgens appear to promote follicular growth (Horie et al. 1992, Wang et al. 2001) and corpus luteum formation (Hu et al. 2004). Therefore, multiple interactions between the cell types forming the follicle involve the interplay of several hormonal, paracrine, and autocrine factors that are essential for ovarian steroid hormone production and follicular maturation.

The prenatal and early postnatal nutritional status plays a critical role in postnatal growth and development. Early malnutrition may change the original programming of organs, especially those in developmental phases, which can result in metabolism long-term changes (Lucas 1994, 1998, Barker 2000). Some authors have shown that lactation could be a critical period in determining the future endocrine status of the progeny (Moura et al. 1997, Passos et al. 2000). Recently, we have shown that maternal protein and energy malnutrition during lactation leads to growth retardation and delay in the onset of puberty in female pups (Faria et al. 2004). Also, protein and energy restriction during lactation leads to an atrophy of the uterine endometrial glands of the offspring at puberty (Brasil et al. 2005).

The maternal nutritional state during lactation is equivalent and possibly even more important than that during gestation, as evidenced by a study by Léonhardt et al. (2003), which showed that the offspring whose dams were malnourished during lactation had more drastic consequences on gonadal development when compared with the offspring whose dams were malnourished only during pregnancy, or during pregnancy and lactation. Guzman et al. (2006) showed similar results. Based on those papers, we decided to analyze the effects of malnutrition only during the lactation time.

The goal of this study was to evaluate whether maternal malnutrition during lactation alters folliculogenesis, the ovarian expression of gonadotropins receptors, AR, and the different isoforms of ERs in the offspring at puberty.

\section{Materials and Methods}

\section{Animals}

Wistar rats were kept in a room with controlled temperature $\left(25 \pm 1^{\circ} \mathrm{C}\right)$ and an artificial light: darkness cycle (lights on from 0700 to $1900 \mathrm{~h}$ ). Virgin female rats of 3 months of age were caged with male rats at a proportion of 2:1. After mating, determined by the presence of a vaginal plug, each female was placed in an individual cage with free access to water and food until delivery. The handling of the animals was approved by the Animal Care and Use Committee of the Biology Institute of State University of Rio de Janeiro, which based their analysis on the Guide for the Care and Use of Laboratory Animals (Bayne 1996), and the study design was approved by the local Ethical Committee for the care and use of laboratory animals.

\section{Experimental design}

Six pregnant Wistar rats were separated after delivery into two groups: control (C) group, with free access to a standard laboratory diet containing $23 \%$ protein and protein-energyrestricted (PER) group, with free access to an isoenergy and protein-restricted diet containing $8 \%$ protein. The PER group, in spite of having free access to diet, consumed about $60 \%$ of that consumed by the control group (Passos et al. 2000). The low-protein diet was prepared in our laboratory 
and its composition is shown in Table 1. Vitamins and mineral mixtures were formulated to meet the American Institute of Nutrition AIN-93G recommendation for rodent diets (Reeves et al. 1993). Within $24 \mathrm{~h}$ of birth, excess pups were removed so that only six female pups were kept per dam, as it has been shown that this procedure maximizes lactation performance (Fishbeck \& Rasmussen 1987). Malnutrition of the studied rats was started at birth, which was defined as day 0 of lactation (d0) and was ended at weaning (d21). After weaning, female pups of the same treatment group were housed in groups of three animals per cage and given unlimited access to food and water until puberty (day 40). Then, only the animals on the diestrum stage were killed with a lethal dose of pentobarbital. To evaluate the nutritional state, food consumption of the offspring was monitored every day from weaning onward, while body weight and linear growth (nose-tail) were monitored every 5 days from birth until the end of the experiment. The blood was collected by cardiac puncture and the serum kept at $-20{ }^{\circ} \mathrm{C}$ for subsequent determination of hormonal parameters. Ovaries were excised, dissected, weighted, and then divided into two parts: one was kept at $-80{ }^{\circ} \mathrm{C}$ for subsequent measurements of androgen receptor, ERs $\alpha$ and $\beta$, FSHR, and LHR transcripts by RT-PCR. The other part of the ovary was paraffin embedded, sectioned at $5 \mu \mathrm{m}$ thickness, and processed by routine histological analyses. Some samples were stained with hematoxylin and eosin to check the integrity of the tissue.

\section{Morphologic classification of follicles}

Paraffin sections $(5 \mu \mathrm{m})$ from the left ovary of five animals from each group were taken at intervals of $50 \mu \mathrm{m}$ and

Table 1 Composition of control and protein-energy-restricted diets

\begin{tabular}{|c|c|c|}
\hline & Control $^{\mathrm{a}}$ & Protein restricted \\
\hline \multicolumn{3}{|l|}{ Ingredients $(\mathrm{g} / \mathrm{kg})$} \\
\hline Total protein ${ }^{\mathrm{C}}$ & $230 \cdot 0$ & $80 \cdot 0$ \\
\hline Cornstarch & $676 \cdot 0$ & $826 \cdot 0$ \\
\hline Soybean oil & $50 \cdot 0$ & $50 \cdot 0$ \\
\hline Vitamin mix ${ }^{d}$ & $4 \cdot 0$ & $4 \cdot 0$ \\
\hline Mineral mix ${ }^{d}$ & $40 \cdot 0$ & $40 \cdot 0$ \\
\hline \multicolumn{3}{|c|}{ Macronutrient composition (\%) } \\
\hline Protein & $23 \cdot 0$ & $8 \cdot 0$ \\
\hline Carbohydrate & $66 \cdot 0$ & $81 \cdot 0$ \\
\hline Fat & $11 \cdot 0$ & $11 \cdot 0$ \\
\hline Total energy $(\mathrm{kJ} / \mathrm{kg})$ & $17038 \cdot 7$ & $17038 \cdot 7$ \\
\hline
\end{tabular}

\footnotetext{
${ }^{a}$ Standard diet for rats (Nuvilab-Nuvital Ltd, Paraná, Brazil).

${ }^{\mathrm{b}}$ The protein-restricted diet was prepared in our laboratory by using the control diet, with replacement of part of its protein content with cornstarch. The amount of the latter was calculated to replace the same energy content of the control diet.

${ }^{c}$ The principal protein resources are soybean wheat, steak, fish, and amino acids.

${ }^{\mathrm{d}}$ Vitamin and mineral mixtures were formulated to meet the American Institute of Nutrition AIN-93G recommendation for rodent diets (Reeves et al. 1993).
}

mounted on slides. The total number of sections analyzed was 15-20 per ovary. Routine hematoxylin and eosin staining was performed for histological examination under a light microscope. Sections from each ovary were digitized using a video camera coupled to a light microscope with a final magnification of X400 for primordial and primary follicles, and X100 for preantral, antral, and Graafian follicles and corpus luteum. Photographs of ovarian follicles were analyzed using Image Pro Plus for Windows (version 1.3.2; Media Cybernetics, Silver Spring, MD, USA). Follicle types in ovarian cross-sections were defined as follows. Primary follicles consisted of an oocyte surrounded by a single layer of cuboidal granulosa cells. Preantral follicles comprised an oocyte surrounded by two or more layers of granulosa cells with no antrum. Antral follicles were distinguished by the presence of an antrum within the granulosa cell layers enclosing the oocyte (Cheng et al. 2002). To avoid double counting, in the growing class only those follicles that showed the nucleus of the oocyte were counted, and in the antral class the follicles were compared with previous sections. The corpora lutea, which are in fact post-antral follicles, were counted in the same way as the follicles in the antral class.

\section{RNA extractions}

Total RNA from ovary tissue was extracted using TRIZOL reagent (Invitrogen) according to the manufacturer's protocol. Briefly, ovaries were homogenized in $1 \mathrm{ml}$ of TRIZOL reagent per $50-100 \mathrm{mg}$ of tissue. Then, RNA was extracted by a phenol/chloroform solution and precipitated by isopropyl alcohol. After washing with 75\% ethanol, the RNA was dried and dissolved with diethyl pyrocarbonatetreated water. The quality of RNA samples was verified by the determination of the ratio $260 / 280 \mathrm{~nm}$ and by electrophoresis on a $1 \%$ agarose gel. The samples were stored at $-80{ }^{\circ} \mathrm{C}$ until utilization.

\section{Semi-quantitative RT-PCR}

All RNA samples were rid of contaminating DNA by using DNA-free reagents (Invitrogen) according to the manufacturer's protocol. Then, $2 \mu \mathrm{g}$ of RNA sample were used in a $20 \mu \mathrm{l}$ cDNA reaction using Oligo dT and the Superscript cDNA synthesis system (Invitrogen) according to the manufacturer's protocol. PCRs were prepared using the equivalent of $2 \mu \mathrm{l}$ cDNA per $50 \mu \mathrm{l}$ reaction (triplicate) for each respective primer set using PCR reagents and Platinum Taq polymerase (Invitrogen). In order to quantify glyceraldehyde-3-phosphate dehydrogenase (Gapdh), $A r, E R \alpha$, $E R \beta 1, E R \beta 2$, Fshr, and Lhcqr transcripts, we determined the optimal number of amplification cycles for each gene. The applied PCR primers and the cycle profiles used are described in Table 2. All amplified cDNA fragments were run on a $1.5 \%$ agarose gel stained with ethidium bromide, visualized under u.v. transillumination, and analyzed with the 
Table 2 Oligonucleotide sequences used for the amplification of RT-PCR and cycling conditions for the different sets of pairs

\begin{tabular}{|c|c|c|c|}
\hline & Sequence $\left(5^{\prime}-3^{\prime}\right)$ & Cycle profile & Number of cycles \\
\hline \multicolumn{4}{|l|}{ Gene } \\
\hline Gapdh & $\begin{array}{l}5^{\prime} \text {-ACC AC AGTCC ATGCC ATC AC-3' } \\
5^{\prime} \text {-TCCACCACCCTGTTGCTGTA-3 } 3^{\prime}\end{array}$ & $\begin{array}{l}94^{\circ} \mathrm{C} / 3 \min , 94^{\circ} \mathrm{C} / 30 \mathrm{~s} \\
58^{\circ} \mathrm{C} / 2 \min , 72^{\circ} \mathrm{C} / 2 \mathrm{~min},\end{array}$ & 30 cycles \\
\hline$A r$ & $\begin{array}{l}\text { 5'-GGAGAACTCTTC AGAGC AAG-3' } \\
5^{\prime} \text {-AGCTGAGTCATCCTGATCTG-3' }\end{array}$ & $\begin{array}{l}94^{\circ} \mathrm{C} / 2 \min , 94^{\circ} \mathrm{C} / 1 \mathrm{~min}, \\
60^{\circ} \mathrm{C} / 1 \mathrm{~min}, 72^{\circ} \mathrm{C} / 1 \mathrm{~min},\end{array}$ & 32 cycles \\
\hline$E r \alpha(E s r 1)$ & $\begin{array}{l}\text { 5'-GGCTACGTCAAGTCGATTCC-3' } \\
\text { 5'-ATCTTGTCCAGGACTCGGTG-3' }\end{array}$ & $\begin{array}{l}94^{\circ} \mathrm{C} / 1 \mathrm{~min}, 60^{\circ} \mathrm{C} / 50 \mathrm{~s}, \\
72^{\circ} \mathrm{C} / 2 \mathrm{~min},\end{array}$ & 30 cycles \\
\hline $\operatorname{Erp} \beta(E s r 2)$ & 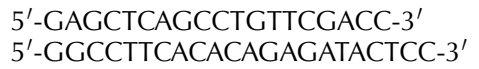 & $\begin{array}{l}94^{\circ} \mathrm{C} / 1 \mathrm{~min}, 60^{\circ} \mathrm{C} / 50 \mathrm{~s}, \\
72{ }^{\circ} \mathrm{C} / 2 \mathrm{~min},\end{array}$ & 30 cycles \\
\hline Fshr & $\begin{array}{l}5^{\prime} \text {-CTCATCAAGCGACACCAAGA-3' } \\
5^{\prime} \text {-GGAAAGGATTGGCACAAGAA-3' }\end{array}$ & $\begin{array}{l}94^{\circ} \mathrm{C} / 2 \min , 94^{\circ} \mathrm{C} / 1 \mathrm{~min}, \\
60^{\circ} \mathrm{C} / 50 \mathrm{~s}, 72^{\circ} \mathrm{C} / 2 \mathrm{~min},\end{array}$ & 36 cycles \\
\hline Lhcqr & $\begin{array}{l}\text { 5'-ATGGCCATCCTCATCTTCAC-3' } \\
\text { 5'-TGGATTGGCACAAGAATTGA-3' }\end{array}$ & $\begin{array}{l}94^{\circ} \mathrm{C} / 2 \mathrm{~min}, 94^{\circ} \mathrm{C} / 1 \mathrm{~min}, \\
60^{\circ} \mathrm{C} / 50 \mathrm{~s}, 72^{\circ} \mathrm{C} / 2 \mathrm{~min}\end{array}$ & 33 cycles \\
\hline
\end{tabular}

Scion Image software (http://www.meyerinst.com/html/ scion/scion_image_windows.htm).

\section{Steroid determinations}

The estradiol and testosterone serum concentrations were determined using a specific RIA for each hormone (MP Biomedicals, Solon, OH, USA). The intra- and inter-assay variation coefficients were $4 \cdot 6$ and $7 \cdot 5 \%$ for testosterone and 6.4 and $5.9 \%$ for estradiol respectively. Sensitivity of the RIA was $0.04 \mathrm{ng} / \mathrm{ml}$ for testosterone and $0.8 \mathrm{pg} / \mathrm{ml}$ for estradiol (Teixeira et al. 2007).

\section{Statistical analysis}

All results are means \pm s.E.M. Statistical analysis was performed by Student's $t$-test. Values of $P<0.05$ were considered significant.

\section{Results}

Figure 1 shows food consumption, body weight, and linear growth of the groups throughout the experiment. Food consumption of the offspring was evaluated from weaning until killing. The PER group had lower food intake than the C group $(P<0.001)$ from weaning until the end of experiment (Fig. 1A). Overall, at each time point of measurement from day 4 after birth until day 40, body weight in the PER group was significantly lower when compared with controls $(P<0 \cdot 001$; Fig. 1B). Similarly, linear growth showed the same pattern, that is the PER group had significantly lower linear growth $(P<0 \cdot 001)$ when compared with controls from day 6 after birth until day 40 (Fig. 1C).

Figure 2 shows the number of ovarian follicles. The offspring whose dams were submitted to PER diets during lactation presented, at puberty, alteration in the number of ovarian follicles. The number of preantral $(C=13 \cdot 72 \pm 2 \cdot 87$; $\mathrm{PER}=26 \cdot 36 \pm 3 \cdot 03, \quad P<0 \cdot 01)$ and small antral follicles $(C=9 \cdot 32 \pm 1 \cdot 35 ;$ PER $=17 \cdot 64 \pm 2 \cdot 33, P<0 \cdot 01)$ was signi- ficantly increased by maternal malnutrition, while the number of primordial follicles $(C=11 \cdot 72 \pm 1 \cdot 37$; PER $=3 \cdot 92 \pm 0 \cdot 60$, $P<0 \cdot 01)$, Graafian follicles $(C=1 \cdot 84 \pm 0 \cdot 21$; PER $=0 \cdot 96 \pm$ $0 \cdot 11, P<0 \cdot 01)$, and corpora lutea $(C=2 \cdot 00 \pm 0 \cdot 28 ; \mathrm{PER}=$ $0 \cdot 80 \pm 0 \cdot 31, P<0 \cdot 01)$ was significantly reduced. The number of primary follicles was increased, but this difference was not significant $(C=2 \cdot 80 \pm 0 \cdot 52 ; \mathrm{PER}=4 \cdot 84 \pm 0 \cdot 90, P>0 \cdot 05)$.

Ovarian sections of offspring are shown in Fig. 3. The primordial follicle consists of an oocyte surrounded by a single layer of relatively undifferentiated granulosa cells (Fig. 3A). Primary follicles consist of an oocyte surrounded by a single layer of cuboidal granulosa cells (Fig. 3B). The preantral follicles present a central oocyte surrounded by several layers of granulosa cells and bounded by thecal cells, which form a fibrous theca externa and an inner theca interna with no antrum. In antral follicles, fluid appeared between the granulosa cells, and the drops coalesced to form follicular fluid within the follicular antrum (Fig. 3C). In Graafian follicles, the follicular antrum is clearly developed, leaving the oocyte surrounded by a distinct and denser layer of granulosa cells, the cumulus oophorus. The corpus luteum is formed by luteal cells and abundant capillaries (Fig. 3D).

The serum estradiol concentration was significantly increased $(C=67 \cdot 86 \pm 4 \cdot 39 ; \quad \mathrm{PER}=83 \cdot 29 \pm 2 \cdot 68, P<0 \cdot 05)$ in PER group while testosterone did not show statistical difference $(C=0 \cdot 09 \pm 0 \cdot 02$; PER $=0 \cdot 11 \pm 0 \cdot 01, P>0 \cdot 05$; Fig. 4).

We performed semi-quantitative RT-PCR in order to determine whether the expression of $A r, E R \alpha, E R \beta 1, E R \beta 2$, $F$ shr, and Lhcqr genes in ovary are affected by protein-energy diet during lactation. Protein-energy maternal restricted diet led to a significant increase in the FSHR $(C=0 \cdot 89 \pm$ $0 \cdot 04 ; \mathrm{PER}=1 \cdot 07 \pm 0 \cdot 03, P<0 \cdot 05)$, and the $\operatorname{LHR}(C=$ $0 \cdot 87 \pm 0 \cdot 15 ; \mathrm{PER}=1 \cdot 33 \pm 0 \cdot 08, P<0 \cdot 05$; Fig. 5). However, there was a decrease in the relative quantity of androgen receptor $(C=0.59 \pm 0.006$; PER $=0.13 \pm 0 \cdot 080, P<0 \cdot 05)$, ESR $1(C=3 \cdot 33 \pm 0 \cdot 71 ; \quad \operatorname{PER}=0 \cdot 74 \pm 0 \cdot 50, \quad P<0 \cdot 05)$, $\operatorname{ER} \beta 1(C=1 \cdot 33 \pm 0 \cdot 06 ; \mathrm{PER}=0 \cdot 49 \pm 0 \cdot 36, P<0 \cdot 05)$, and $\operatorname{ER} \beta 2(C=3 \cdot 28 \pm 0 \cdot 60 ; \operatorname{PER}=0.62 \pm 0 \cdot 34, P<0 \cdot 05)$ in the PER group (Fig. 6). 

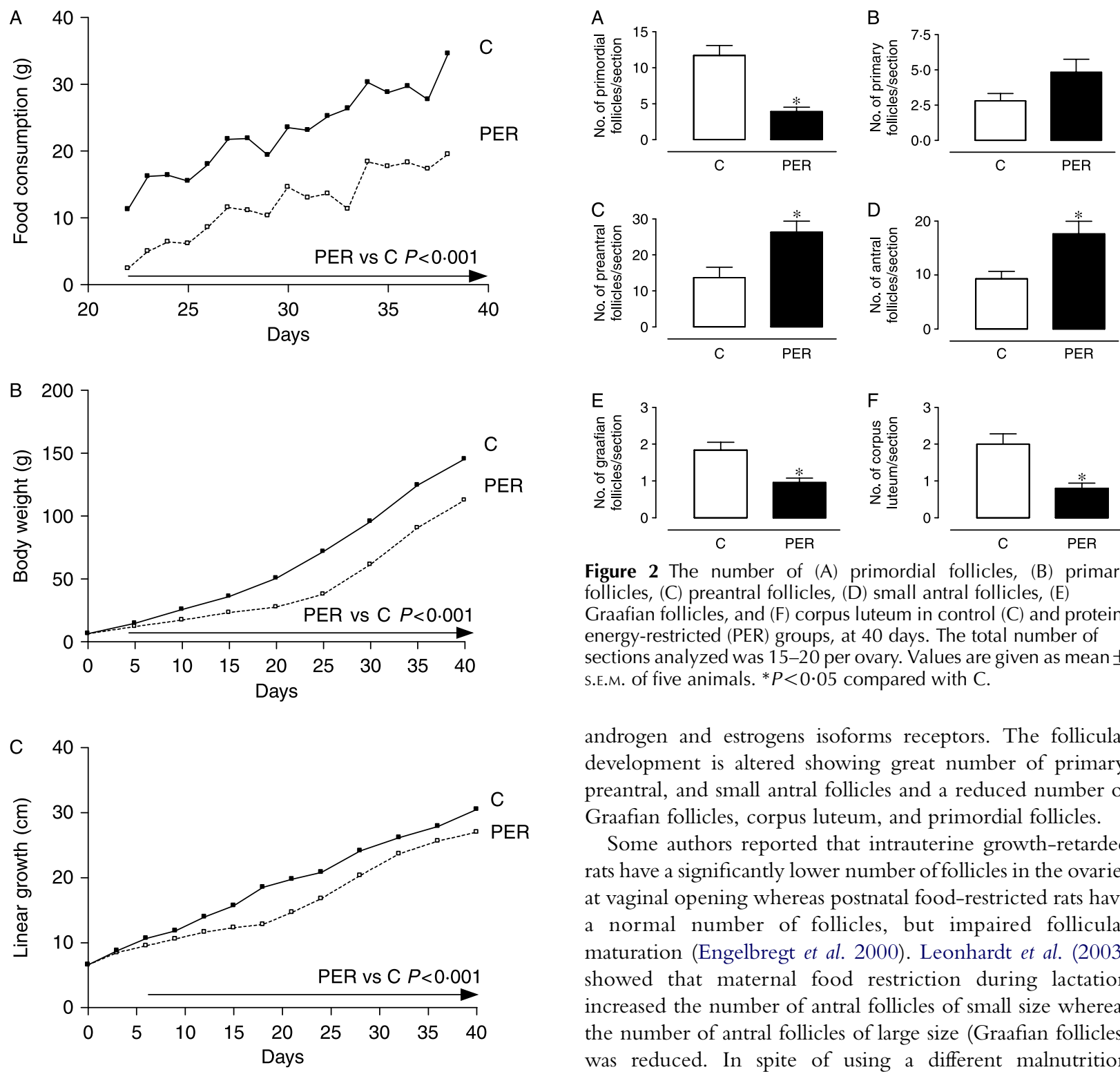

Figure 1 (A) Food consumption, (B) body weight, and (C) linear growth (nose-tail) in control (C) group and protein-energy-restricted (PER) group. Values are given as mean \pm s.D. of 14 animals.

The pattern of expression of the different ER isoforms was different between the $\mathrm{C}$ and PER groups. Considering $\mathrm{ER} \beta$ as the sum of ER $\beta 1$ and $E R \beta 2$, the ER $\beta / E R \alpha$ ratio was 1.3 in the $C$ group and increased to 1.5 in the PER group. The ER $\beta 2 / E R \beta 1$ ratio was $2 \cdot 5$ in the $C$ group and decreased to $1 \cdot 2$ in the PER group.

\section{Discussion}

The present data show that maternal malnutrition during lactation leads to alterations in the ovarian expression of FSH,
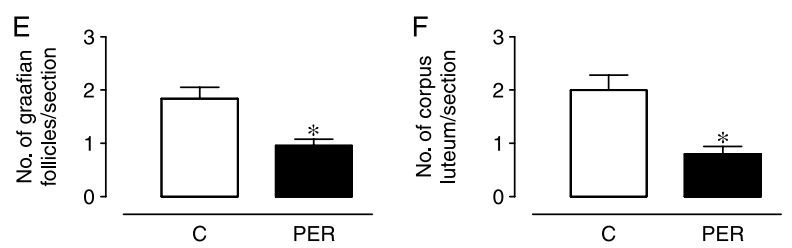

Figure 2 The number of (A) primordial follicles, (B) primary follicles, (C) preantral follicles, (D) small antral follicles, (E) Graafian follicles, and (F) corpus luteum in control (C) and proteinenergy-restricted (PER) groups, at 40 days. The total number of sections analyzed was 15-20 per ovary. Values are given as mean \pm S.E.M. of five animals. ${ }^{*} P<0.05$ compared with $C$.

androgen and estrogens isoforms receptors. The follicular development is altered showing great number of primary, preantral, and small antral follicles and a reduced number of Graafian follicles, corpus luteum, and primordial follicles.

Some authors reported that intrauterine growth-retarded rats have a significantly lower number of follicles in the ovaries at vaginal opening whereas postnatal food-restricted rats have a normal number of follicles, but impaired follicular maturation (Engelbregt et al. 2000). Leonhardt et al. (2003) showed that maternal food restriction during lactation increased the number of antral follicles of small size whereas the number of antral follicles of large size (Graafian follicles) was reduced. In spite of using a different malnutrition experimental model, our data show that maternal malnutrition during lactation disturbed the follicular development, with an increment in the number of growing follicles and a reduction in the Graafian follicles number, suggesting an impaired follicular maturation since not all growing follicles reach the ovulatory stage.

FSH is, undoubtedly, the primary stimulus for the differentiation of follicles from the preantral to preovulatory stage. As the ovarian follicles grow and differentiate, increasing amounts of estrogen are produced (Fortune 1994), which, in turn, upregulate the synthesis and release of the pituitary gonadotropins, thereby promoting the upregulation of FSHR and consequent ovarian follicular growth that culminates in ovulation (Lapolt et al. 1992, Tano et al. 1999). Female mice null for FSH signaling due to the loss 


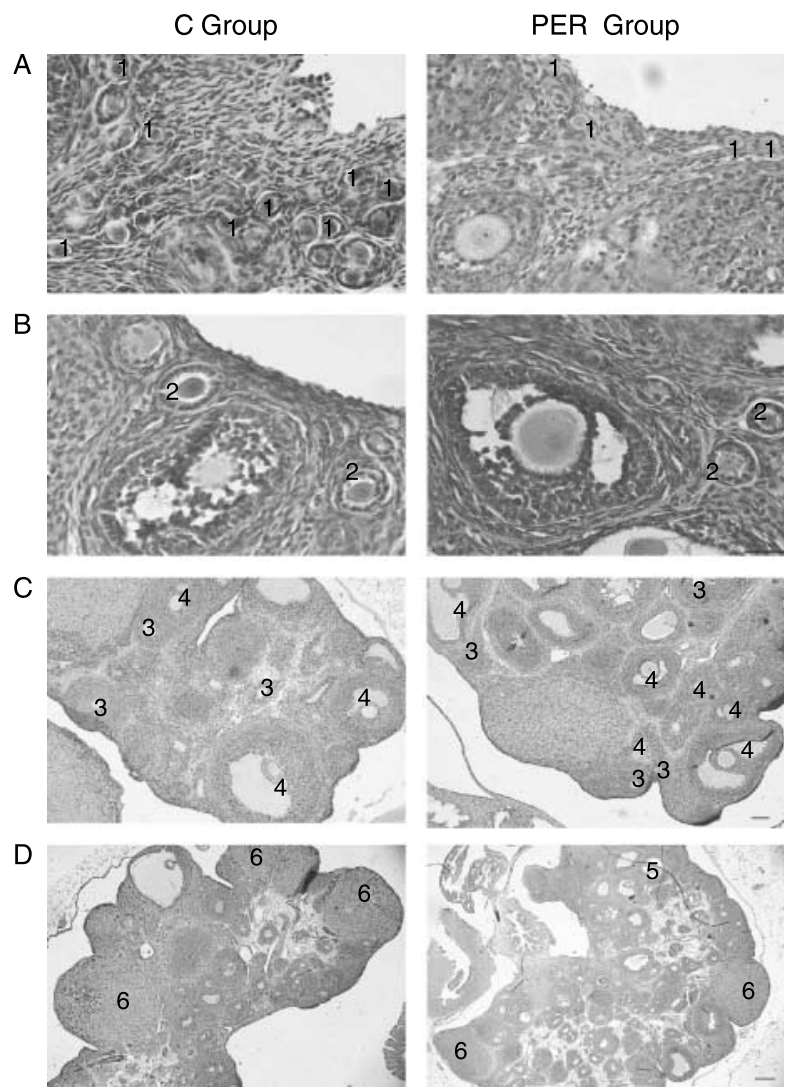

Figure 3 Photomicrographs showing ovaries from female rat pups at puberty in control (C) and protein-energy-restricted (PER) groups. (A) Primordial follicles (1); (B) primary follicles (2); (C) preantral follicles (3), antral follicles (4); (D) Graafian follicles (5), corpus luteum (6). Magnification: (A) $\times 400$; (B) $\times 400$; (C) $\times 100$; (D) $\times 40$ (bar $100 \mu \mathrm{m}$ ).

of hormone (Kumar et al. 1997, Burns et al. 2001) or receptor (Dierich et al. 1998, Danilovich et al. 2001) exhibit follicles that fail to differentiate beyond the preantral stage and produce minimal estradiol and hence are infertile. However, FSH alone does not provide for complete follicle and granulosa cell differentiation. Instead, the synergistic actions of estradiol are required to maximize FSH induction of antrum formation (Hirshfield 1991, Emmen et al. 2005) and $\mathrm{LH}$ responsiveness (Knecht et al. 1984, 1985a,b). Also, estrogen seems to directly increase the number and size of ovarian follicles (Goldenberg et al. 1972, Nakayama et al. 1981, Nakano et al. 1982, Gore-Langton \& Daniel 1990, Nayudu \& Osborn 1992, Hulshof et al. 1995), regulate corpus luteum formation, and control luteal maintenance (Krege et al. 1998, Britt et al. 2000, Dupont et al. 2000, Rosenfeld et al. 2000). So, the increment observed in the number of primary, preantral, and small antral follicles in the offspring at puberty following maternal malnutrition during lactation could be consequent to the increase in the ovary FSHR expression and estradiol serum concentration presented by these animals.
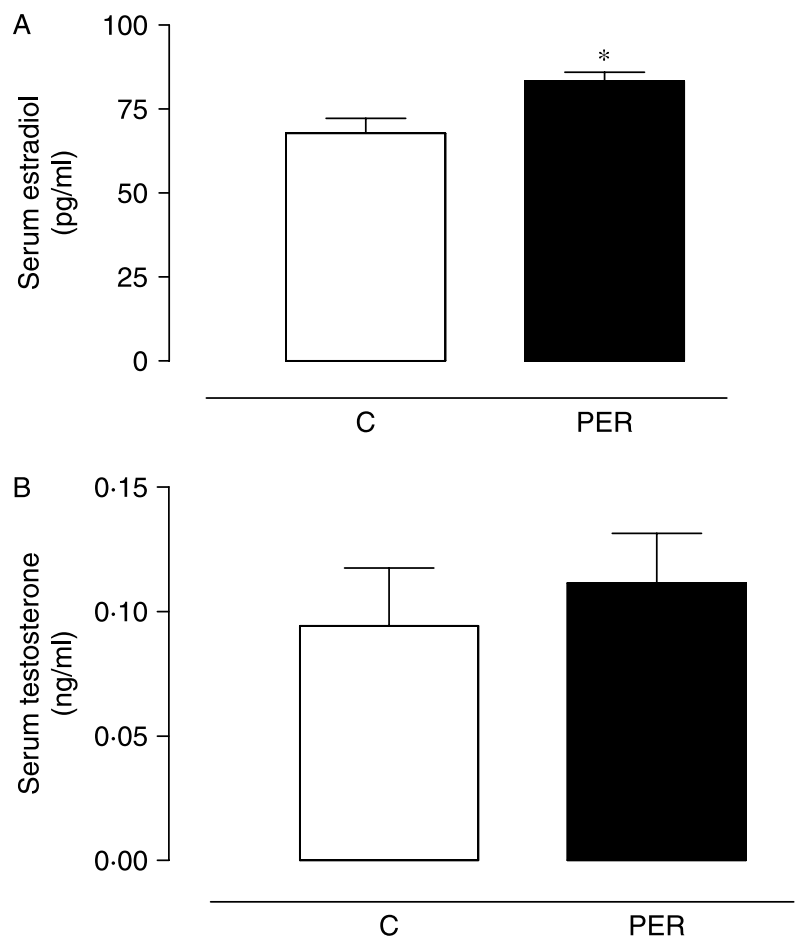

Figure 4 (A) Serum estradiol concentration and (B) serum testosterone concentrations in control $(\mathrm{C})$ and protein-energyrestricted (PER) groups, at 40 days. Values are given as means \pm S.E.M. of seven animals per group. ${ }^{*} P<0 \cdot 05$ compared with $\mathrm{C}$.

In this paper, we confirm previous studies which show that there is a predominance of $\operatorname{ER} \beta$ over $\operatorname{ER} \alpha$ expression in the ovary (Byers et al. 1997, Drummond et al. 1999). We also show that the $\operatorname{ER} \beta / \mathrm{ER} \alpha$ ratio is even higher after maternal malnutrition during lactation, probably due to the increase observed in the number of growing follicles in this group, since previous results show that ER $\beta$ increases in synergy with the proliferation of granulosa cells (Drummond et al. 1999).

A number of variant forms of ER $\beta$ have been identified with different patterns of expression (Chu \& Fuller 1997). According to our data, Drummond et al. (1999) showed that ovary of immature rats expresses more ER $\beta 2$ than ER $\beta 1$ isoform, and also that the $\operatorname{ER} \beta 2 / \operatorname{ER} \beta 1$ ratio increases with age. Maternal malnutrition during lactation caused a reduction in the ER $\beta 2 / E R \beta 1$ ratio. This could be explained by the fact that these animals present growth retardation and delay in the onset of puberty (Faria et al. 2004), suggesting that they are more immature than the control group.

We have no previous knowledge about how maternal malnutrition influences the expression of ER isoforms or how the ER isoforms expression alteration showed here could affect the ovarian function. However, we can hypothesize that the follicular growth alteration in the malnourished group can be related to the change of balance among $\operatorname{ER} \alpha, \operatorname{ER} \beta 1$, and ER $\beta 2$ expressions since the ER $\beta$ isoforms can differentially modulate estrogen action (Peng et al. 2003). 
A
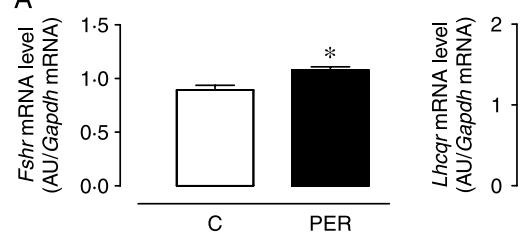

B

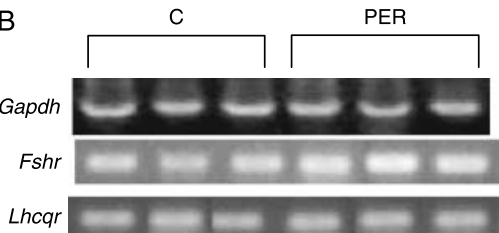

Figure 5 Expression of Fshr and Lhcqrgenes in ovaries of control (C) and protein-energy-restricted (PER) groups. After RT-PCR reactions, the amplified fragments were run on a $1.5 \%$ agarose gel and visualized by u.v. transillumination. (A) Graphical representation of the data. (B) A representative ethidium bromide-stained gel depicting products for the expression of Gapdh, Fshr, and Lhcqr genes in ovaries. The ratios between the signal intensities (arbitrary units) of Fshr and Lhcqr are represented as means \pm S.E.M. of three animals. ${ }^{*} P<0 \cdot 05$ compared with $\mathrm{C}$.

Despite normal testosterone and high estradiol serum concentrations, the low $\mathrm{ER} \alpha, \mathrm{ER} \beta$, and $\mathrm{AR}$ expressions could have contributed to the alterations in the antrum and corpus luteum formation leading to a reduction in the number of Graafian follicles and corpus luteum. It has been shown that
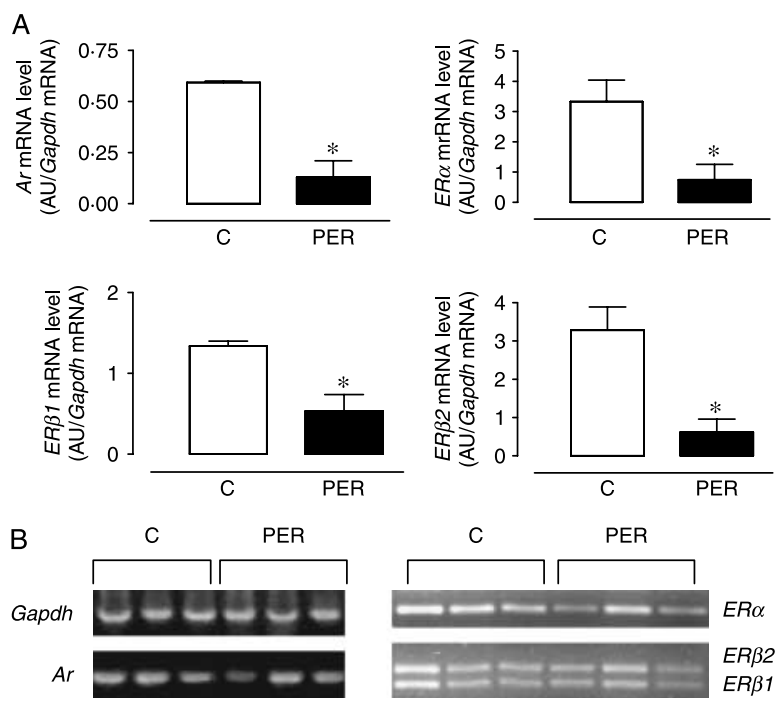

Figure 6 Expression of $A r, E R \alpha, E R \beta 1$, and $E R \beta 2$ genes in ovaries of control (C) and protein-energy-restricted (PER) groups. After RT-PCR reactions, the amplified fragments were run on a $2 \%$ agarose gel and visualized by u.v. transillumination. (A) Graphically representation of the data. (B) A representative ethidium bromide-stained gel depicting products for the expression of Gapdh, $A r, E R \alpha, E R \beta 1$, and $E R \beta 2$ genes in ovaries. The ratios between the signal intensities (arbitrary units) of $A r, E R \alpha, E R \beta 1$, and $E R \beta 2$ are represented as means \pm S.E.M. of three animals. ${ }^{*} P<0.05$ compared with $C$.
$\mathrm{AR}$ and ER $\beta$ double knockout mice do not undergo luteinization and corpus luteum formation (Fisher et al. 1998, Couse et al. 1999, Britt et al. 2000, Dupont et al. 2000). Also, since some signaling events that are critical for the final follicle growth and eventual ovulation are altered by perinatal malnutrition, like leptin (Teixeira et al. 2002), insulin (Moura et al. 2002) etc., we can suggest that a high LHR expression was not capable of stimulating the final maturation of Graafian follicles without the presence of those signaling factors.

Primordial follicles are the stock from which all growing follicles are derived. Some hypothesis could explain the reduced number in the primordial follicles observed in the offspring whose mothers were submitted to malnutrition during lactation. First of all, in rodents, the primordial follicles are formed by day 3 of age, and the first wave of follicles develop into antral follicles over the next 3 weeks (Rajah et al. 1992, Gelety \& Magoffin 1997, McGee et al. 1997). We have published recently that, in this period, these animals show significant alterations in their body weight and thyroid function as well as in the milk composition (Passos et al. 2000, 2001, Ramos et al. 2000). Thus, it is possible that the decrease observed in the number of primordial follicles could result from a direct action of malnutrition in the ovary of the pups in the first days of life when primordial follicles are being formed. Secondly, the increase in the primary, preantral, and antral follicles observed in these animals could result in a gradual decrease in the original follicle pool, which is stimulated to enter the growth phase.

Recently, Guzman et al. (2006), using a similar model of malnutrition during lactation, have shown that 1-year-old rats presented an increase in the estrous cycle length and reduced fertility rate. Our data of reduced primordial follicle number could explain this fact, suggesting that the reduction of follicular reserve that serves as a ticking clock to the onset of senescence could be responsible for the decrease in the fertility rate.

In conclusion, perinatal maternal malnutrition can directly affect folliculogenesis at puberty probably as a consequence of changes in the ovarian expression of gonadotropins, androgen and estrogen isoform receptors. Long-term sexual alterations could be expected in this experimental model, since a reduction in the primordial follicle number is observed, which can result in a decrease in reproductive lifetime and an earlier termination of breeding capacity.

\section{Declaration of Interest}

The authors declare that there is no conflict of interest that would prejudice the impartiality of this scientific work.

\section{Funding}

This work was supported by grants from the National Council of Scientific and Technological Development $(\mathrm{CNPq})$, the Foundation for Research 
Support of Rio de Janeiro (FAPERJ), the Coordination for Improvement of Post-Graduated Students (CAPES), and the State University of Rio de Janeiro (UERJ-SR2), Brazil.

\section{References}

Barker DJP 2000 In utero programming of cardiovascular disease. Theriogenology 53 555-574.

Bayne K 1996 Revised guide for the care and use of laboratory animals available. American physiological society. Physiologist 39 208-211.

Brasil FB, Faria TS, Costa WS, Sampaio FJB \& Ramos CF 2005 The pups' endometrium morphology is affected by maternal malnutrition during suckling. Maturitas $\mathbf{5 1} 405-412$.

Britt KL, Drummond AE, Cox VA, Dyson M, Wreford NG, Jones MEE, Simpson ER \& Findlay JK 2000 An age-related ovarian phenotype in mice with targeted disruption of the Cyp 19 (Aromatase) gene. Endocrinology 141 2614-2623.

Burns KH, Yan C, Kumar TR \& Matzuk MM 2001 Analysis of ovarian gene expression in follicle-stimulating hormone beta knockout mice. Endocrinology 142 2742-2751.

Byers M, Kuiper GG, Gustafsson J-A \& Park-Sarge O-K 1997 Oestrogen receptor- $\beta$ mRNA expression in rat ovary: down-regulation by gonadotropins. Molecular Endocrinology 11 172-182.

Cheng G, Weihua Z, Makinen S, Makela S, Saji S, Warner M, Gustafsson JA \& Hovatta O 2002 A role for the androgen receptor in follicular atresia of estrogen receptor beta knockout mouse ovary. Biology of Reproduction 66 77-84.

Chu S \& Fuller PJ 1997 Identification of a splice variant of the rat estrogen receptor beta gene. Molecular and Cellular Endocrinology 132 195-199.

Chun TY, Gregg D, Sarkar DK \& Gorski J 1998 Differential regulation by estrogens of growth and prolactin synthesis in pituitary cells suggests that only a small pool of estrogen receptors is required for growth. PNAS 95 2325-2330

Clark JH, Schrader WT \& O'Malley BW 1992 Mechanisms of action of steroid hormones. In Textbook of Endocrinology, pp 35-90. Eds JD Wilson \& DW Foster. New York: Saunders.

Conneely OM, Mulac-Jericevic B, Lydon JP \& DeMayo FJ 2001

Reproductive functions of the progesterone receptor isoforms: lessons from knockout mice. Molecular and Cellular Endocrinology 179 97-103.

Couse JF, Curtis-Hewitt S, Bunch DO, Sar M, Walker VR, Davis BJ \& Korach KS 1999 Postnatal sex reversal of the ovaries in mice lacking estrogen receptors alpha and beta. Science 286 2328-2331.

Couse JF, Yates MM, Deroo BJ \& Korach KS 2005 Estrogen receptor- $\beta$ is critical to granulose cell differentiation and the ovulatory response to gonadotripins. Endocrinology 146 3247-3262.

Danilovich N, Roy I \& Sairam MR 2001 Ovarian pathology and high incidence of sex cord tumors in follitropin receptor knockout (FORKO) mice. Endocrinology 142 3673-3684.

Davis BJ, Lennard DE, Lee CA, Tiano HF, Morham SG, Wetsel WC \& Langenbach R 1999 Anovulation in cyclo-oxygenase-2-deficient mice is restored by prostaglandin E2 and interleukin-1b. Endocrinology 140 2685-2696.

Dierich A, Sairam MR, Monaco L, Fimia GM, Gansmuller A, LeMeur M \& Sassone-Corsi P 1998 Impairing follicle-stimulating hormone (FSH) signaling in vivo: targeted disruption of the FSH receptor leads to aberrant gametogenesis and hormonal imbalance. PNAS 95 13612-13617.

Drummond AE \& Findlay JK 1999 The role of estrogen in folliculogenesis. Molecular and Cellular Endocrinology 151 57-64.

Drummond AE, Baillie AJ \& Findlay JK 1999 Ovarian oestrogen receptor $\alpha$ and $\beta$ mRNA expression: impact of development and oestrogen. Molecular and Cellular Endocrinology 149 153-161.

Dupont S, Krust A, Gansmuller A, Dierich A, Chambon P \& Mark M 2000 Effect of single and compound knockouts of estrogen receptors alpha $(\mathrm{ER} \alpha)$ and beta $(\mathrm{ER} \beta)$ on mouse reproductive phenotypes. Development 127 4277-4291.
Emmen JMA, Couse JF, Elmore SA, Yates MM, Kissling GE \& Korach KS 2005 In vitro growth and ovulation of follicles from ovaries of estrogen receptor (ER) $\alpha$ and ER $\beta$ null mice indicate a role for ER $\beta$ in follicular maturation. Endocrinology 146 2817-2826.

Engelbregt MJT, Houdjik MECAM, Popp-Snijders C \& Delemarre-Van de Wall HA 2000 The effects of intra-uterine growth retardation and postnatal undernutrition on onset of puberty in male and female rats. Pediatric Research 48 803-807.

Faria TS, Ramos CF \& Sampaio FJB 2004 Puberty onset in the female offspring of rats submitted to protein or energy restricted diet during lactation. Journal of Nutritional Biochemistry 5 123-127.

Fishbeck KL \& Rasmussen KM 1987 Effect of repeated cycles on maternal nutritional status, lactational performance and litter growth in ad libitum-fed and chronically food-restricted rats. Journal of Nutrition 117 1967-1975.

Fisher CR, Graves KH, Parlow AF \& Simpson ER 1998 Characterization of mice deficient in aromatase (ArKO) because of targeted disruption of the cyp19 gene. PNAS 95 6965-6970.

Fortune JE 1994 Ovarian follicular growth and development in mammals. Biology of Reproduction 50 225-232.

Gelety TJ \& Magoffin DA 1997 Ontogeny of steroidogenic enzyme gene expression in ovarian theca-interstitial cells in the rat: regulation by a paracrine theca-differentiating factor prior to achieving luteinizing hormone responsiveness. Biology of Reproduction 56 938-945.

Goldenberg RL, Vaitukaitis JL \& Ross GT 1972 Estrogen and follicle stimulation hormone interactions on follicle growth in rats. Endocrinology 90 1492-1498.

Gore-Langton RE \& Daniel SAJ 1990 Follicle-stimulating hormone and estradiol regulate antrum-like reorganization of granulosa cells in rat preantral follicle cultures. Biology of Reproduction 43 65-72.

Gougeon A 1996 Regulation of ovarian follicular development in primates: facts and hypotheses. Endocrine Reviews 17 121-155.

Guzmán C, Cabrera R, Cárdenas M, Larrea F, Nathanielsz PW \& Zambrano E 2006 Protein restriction during fetal and neonatal development in the rat alters reproductive function and accelerates reproductive ageing in female progeny. Journal of Physiology $\mathbf{5 7 2}$ 97-108.

Hirshfield AN 1991 Development of follicles in the mammalian ovary. International Review of Cytology 124 43-101.

Hizaki H, Segi E, Sugimoto Y, Hirose M, Saji T, Ushikubi F, Matsuoka T, Noda Y, Tanaka T, Yoshida N et al. 1999 Abortive expansion of the cumulus and impaired fertility in mice lacking the prostaglandin $\mathrm{E}$ receptor subtype EP(2). PNAS 96 10501-10506.

Horie K, Takakura K, Fujiwara H, Suginami H, Liao S \& Mori T 1992 Immunohistochemical localization of androgen receptor in the human ovary throughout the menstrual cycle in relation to estrogen and progesterone receptor expression. Human Reproduction 7 184-190.

Hu YC, Wang PH, Yeh S, Wang RS, Xie C, Xu Q, Zhou X, Chao HT, Tsai MY \& Chang C 2004 Subfertility and defective folliculogenesis in female mice lacking androgen receptor. PNAS 101 11209-11214.

Hulshof SCJ, Figueiredo JR, Beckers JF, Beyers MM, van der Donk JA \& Van Den Hurk R 1995 Effects of fetal bovine serum, FSH, and 17ß-estradiol on the culture of bovine preantral follicles. Theriogenology 44 217-226.

Joyce IM, Pendola FL, O’Brien M \& Eppig JJ 2001 Regulation of prostaglandinendoperoxide synthase 2 messenger ribonucleic acid expression in mouse granulosa cells during ovulation. Endocrinology 142 3187-3197.

Kimura S, Matsumoto T, Matsuyama R, Shiina H, Sato T, Takeyama K \& Kato S 2007 Androgen receptor function in folliculogenesis and its clinical implication in premature ovarian failure. Trends in Endocrinology and Metabolism 18 183-189.

Knecht M, Darbon JM, Ranta T, Baukal AJ \& Catt KJ 1984 Estrogens enhance the adenosine $3^{\prime}, 5^{\prime}$-monophosphate-mediated induction of follicle-stimulating hormone and luteinizing hormone receptors in rat granulosa cells. Endocrinology 115 41-49.

Knecht M, Brodie AM \& Catt KJ 1985a Aromatase inhibitors prevent granulose cell differentiation: an obligatory role for estrogens in luteinizing hormone receptor expression. Endocrinology 117 1156-1161. 
Knecht M, Tsai-Morris CH \& Catt KJ $1985 b$ Estrogen dependence of luteinizing hormone receptor expression in cultured rat granulosa cells. Inhibition of granulosa cell development by the antiestrogens tamoxifen and keoxifene. Endocrinology 116 1771-1777.

Korach KS, Migliaccio S \& Davis VL 1995 Estrogens. In Principles of Pharmacology: Basic Concepts and Clinical Applications, pp 827-836. Ed. PL Munson. New York: Chapman \& Hall.

Krege JH, Hodgin JB, Couse JF, Enmark E, Warner M, Mahler JF, Sar M, Korach KS, Gustafsson J-A \& Smithies O 1998 Generation and reproductive phenotypes of mice lacking estrogen receptor $\beta$. PNAS 95 $15677-15682$.

Kumar TR, Wang Y, Lu N \& Matzuk MM 1997 Follicle stimulating hormone is required for ovarian follicle maturation but not male fertility. Nature Genetics 15 201-204.

Lapolt PS, Tilly JL, Aihara T, Nishimori K \& Hsueh AJ 1992 Gonadotropininduced up- and down-regulation of ovarian follicle-stimulating hormone (FSH) receptor gene expression in immature rats: effects of pregnant mare's serum gonadotropin, human chorionic gonadotropin, and recombinant FSH. Endocrinology 130 1289-1295.

Leonhardt M, Lesage J, Croix D, Dutriez-Casteloot I, Beuvillain JC \& Dupouy JP 2003 Effects of perinatal maternal food restriction on pituitarygonadal axis and plasma leptin level in rat pup at birth and weaning and on timing of puberty. Biology of Reproduction 68 390-400.

Lindberg MK, Movérare S, Skrtic S, Gao H, Dahlman-Wright K, Gustafsson JA \& Ohlsson C 2003 Estrogen receptor (ER)- $\beta$ reduces ER $\alpha$-regulated gene transcription, supporting a 'ying yang' relationship between ER $\alpha$ and ER $\beta$ in mice. Molecular Endocrinology 17 203-208.

Liu MM, Albanese C, Anderson CM, Hilty K, Webb P, Uht RM, Price RHJr, Pestell RG \& Kushner PJ 2002 Opposing action of estrogen receptors $\alpha$ and $\beta$ on cyclin D1 gene expression. Journal of Biological Chemistry 277 24353-24360.

Lucas A 1994 Role of nutritional programming in determining adult morbidity. Archives of Disease in Childhood 71 288-290.

Lucas A 1998 Programming by early nutrition: an experimental approach. Journal of Nutrition 128 401S-406S.

Lydon JP, DeMayo FJ, Funk CR, Mani SK, Hughes AR, Montgomery CA Jr, Shyamala G, Conneely OM \& O’Malley BW 1995 Mice lacking progesterone receptor exhibit reproductive abnormalities. Genes and Development 9 2266-2278.

Maruyama K, Endoh H, Sasaki-Iwaoka H, Kanou H, Shimaya E, Hashimoto S, Kato S \& Kawashima H 1998 A novel isoform of rat estrogen receptor beta with 18 amino acid insertion in the ligand binding domain as a putative dominant negative regulator of estrogen action. Biochemical and Biophysical Research Communications 246 142-147.

McFarland KC, Sprengel R, Phillips HS, Kohler M, Rosemblit N, Nikolics K, Segaloff DL \& Seeburg PH 1989 Lutropin-choriogonadotropin receptor: an unusual member of the G protein-coupled receptor family. Science $\mathbf{2 4 5}$ 494-499.

McGee EA, Perlas E, LaPolt PS, Tsafriri A \& Hsueh AJW 1997 Folliclestimulating hormone enhances the development of preantral follicles in juvenile rats. Biology of Reproduction 57 990-998.

Moura AS, Caldeira Filho JS, Mathias PC \& Franco de Sá CCN 1997 Insulin secretion impairment and insulin sensitivity improvement in adults rats undernourished during early lactation. Research Communications in Molelcular Pathology and Pharmacology 96 180-192.

Moura AS, Franco de Sá CC, Cruz HG \& Costa CL 2002 Malnutrition during lactation as a metabolic imprinting factor inducing the feeding pattern of offspring rats when adults. The role of insulin and leptin. Brazilian Journal of Medical and Biological Research 35 617-622.

Nakano R, Nakayama T \& Iwao M 1982 Inhibition of ovarian follicle growth by a chemical antiestrogen. Hormone Research 16 230-236.

Nakayama T, Nakano R \& Iwao M 1981 Evidence for a role of endogenous estrogen on follicular growth in immature female rats. Endocrinologia Japonica 28 715-723.

Nayudu PL \& Osborn SM 1992 Factors influencing the rate of preantral and antral growth of mouse ovarian follicles in vitro. Journal of Reproduction and Fertility 95 349-362.
Paech K, Webb P, Kuiper GG, Nilsson S, Gustafsson J, Kushner PJ \& Scanlan TS 1997 Differential ligand activation of estrogen receptors ER $\alpha$ and ER $\beta$ at AP1 sites. Science 277 1508-1510.

Passos MCF, Ramos CF \& Moura EG 2000 Short and long term effects of malnutrition in rats during lactation on the body weight of offspring. Nutrition Research 20 1603-1612.

Passos MCF, Ramos CF, Dutra SCP \& Moura EG 2001 Transfer of iodine through the milk in protein-restricted lactating rats. Journal of Nutritional Biochemistry 2 300-303.

Peng B, Lu B, Leygue E \& Murphy LC 2003 Putative functional characteristics of human estrogen receptor-beta isoforms. Journal of Molecular Endocrinology 30 13-29.

Petersen DN, Tkalcevic GT, Koza-Taylor PH, Turi TG \& Brown TA 1998 Identification of estrogen receptor $\beta 2$, a functional variant of estrogen receptor beta expressed in normal rat tissues. Endocrinology 139 1082-1092.

Price RH Jr \& Handa RJ 2000 Expression of estrogen receptor-beta protein and mRNA in the cerebellum of the rat. Neuroscience Letters $\mathbf{2 8 8}$ $115-118$.

Rajah R, Glaser EM \& Hirshfield NA 1992 The changing architecture of the neonatal rat ovary during histogenesis. Developmental Dynamics 194 177-192.

Ramos CF, Teixeira CV, Passos MCF, Pazos-Moura CC, Lisboa PC, Curty FH \& Moura EG 2000 Low-protein diet changes thyroid function in lactating rats. Proceedings of the Society for Experimental Biology and Medicine 224 256-263.

Reeves PG, Nielsen FH \& Fahey GC 1993 AIN-93 purified diets for laboratory rodents: final report of the American Institute of Nutrition Ad Hoc Writing Committee on the reformulation of the AIN-76 rodent diet. Journal of Nutrition 123 1939-1951.

Ricci AG, Di Yorio MP \& Faletti AG 2006 Inhibitory effect of leptin on the rat ovary during the ovulatory process. Reproduction 132 771-780.

Richards JS 1994 Hormonal control of gene expression in the ovary. Endocrine Reviews 15 725-751.

Richards JS, Russell DL, Ochsner S \& Espey LL 2002 Ovulation: new dimensions and new regulators of the inflammatory-like response. Annual Review of Physiology 64 69-92.

Robker RL, Russell DL, Espey LL, Lydon JP, O'Malley BW \& Richards JS 2000 Progesterone-regulated genes in the ovulation process: ADAMTS-1 and cathepsin L proteases. PNAS 97 4689-4694.

Rosenfeld CS, Murray AA, Simmer G, Hufford MG, Smith MF, Spears N \& Lubahn DB 2000 Gonadotropin induction of ovulation and corpus luteum formation in young estrogen receptor- $\alpha$ knockout mice. Biology of Reproduction 62 599-605.

Ryan NK, Van Der Hoek KH, Robertson SA \& Norman RJ 2003 Leptin and leptin receptor expression in the rat ovary. Endocrinology 144 5006-5013.

Shimada M, Gonzalez-Robayna I, Hernandez-Gonzalez I \& Richards JS 2006 Paracrine and autocrine regulation of EGF-like factors in cumulus oocyte complexes and granulosa cells: key role for prostaglandin synthase 2 (Ptgs2) and progesterone receptor (Pgr). Molecular Endocrinology 20 1352-1365.

Sirois J, Simmons DL \& Richards JS 1992 Hormonal regulation of messenger ribonucleic acid encoding a novel isoform of prostaglandin endoperoxide $\mathrm{H}$ synthase in rat preovulatory follicles. Journal of Biological Chemistry 267 11586-11592.

Sprengel R, Braun T, Nikolics K, Segaloff DL \& Seeburg PH 1990 The testicular receptor for follicle stimulating hormone: structure and functional expression of cloned cDNA. Molecular Endocrinology 4 525-530.

Tamura K, Matsushita M, Endo A, Kutsukake M \& Kogo H 2007 Effect of insulin-like growth factor-binding protein 7 on steroidogenesis in granulosa cells derived from equine chorionic gonadotropin-primed immature rat ovaries. Biology of Reproduction 77 485-491.

Tano M, Minegishi T, Kishi H, Kameda T, Abe Y \& Miyamoto K 1999 The effect of follicle-stimulating hormone (FSH) on the expression of Fsh receptor in cultured rat granulosa cells. Life Sciences 64 1063-1069. 
Teixeira C, Passos M, Ramos C, Dutra S \& Moura E 2002 Leptin serum concentration, food intake and body weight in rats whose mothers were exposed to malnutrition during lactation. Journal of Nutritional Biochemistry 13 493-498.

Teixeira C, Silandre D, Santos AMS, Delalande C, Sampaio FJB, Carreau S \& Ramos CF 2007 Effects of maternal undernutrition during lactation on aromatase, estrogen, and androgen receptors expression in rat testis at weaning. Journal of Endocrinology 192 301-311.

Themmen APN \& Huhtaniemi IT 2000 Mutations of gonadotropins and gonadotropin receptors: elucidating the physiology and pathophysiology of pituitary-gonadal function. Endocrine Reviews 21 551-583.

Vitt UA, Hayashi M, Klein C \& Hsueh AJW 2000 Growth differentiation factor-9 stimulates proliferation but suppresses the follicle-stimulating hormone-induced differentiation of cultured granulosa cells from small antral and preovulatory rat follicles. Biology of Reproduction 62 370-377.
Wang H, Andoh K, Hagiwara H, Xiaowei L, Kikuchi N, Abe Y, Yamada K, Fatima R \& Mizunuma H 2001 Effect of adrenal and ovarian androgens on type 4 follicles unresponsive to FSH in immature mice. Endocrinology 142 4930-4936.

Wong WYW \& Richards JS 1991 Evidence for two antigenically distinct molecular weight variants of prostaglandin $\mathrm{H}$ synthase in the rat ovary. Molecular Endocrinology 5 1269-1279.

Received in final form 4 June 2008

Accepted 2 July 2008

Made available online as an Accepted Preprint

2 July 2008 